\title{
Textologické marginálie k Sládkovičovej Maríne Martin Navrátil
}

\author{
NAVRÁTIL, M.: Textological marginalia on Sládkovič's Marína \\ SLOVENSKÁ LITERATÚRA 68, 2021, No. 2, p. 123-134 \\ DOI: https://doi.org/10.31577/slovlit.2021.68.2.4 \\ ORCID ID: 0000-0001-6944-3254
}

\section{Key words: Andrej Sládkovič, Jozef Karol Viktorin, Cyril Kraus, editorial work}

In 1846, one of the most important works of Slovak literary Romanticism, Andrej Sládkovič's (1820-1872) long poem Marína written in the newly-codified Slovak language, was published. Its second edition, which took into account the dynamic development of this young language, played an important role in the publishing tradition of the poem. Sládkovič revised it in cooperation with the editor Karol Viktorin (1822-1874) and it was printed in the series Spisy básnické Andreja Sládkoviča [Poetic writings of Andrej Sládkovič]. Since then, several editors attempted at bringing forth their editions of this canonical work. The latest edition was prepared by Cyril Kraus (1928-2012) at a time of a rapid development of Slovak textology. The period publishing conditions were also favourable and owing to these, Kraus not only had the largest corpus of sources at his disposal, but could also rely on these relatively developed publishing techniques. His text has become the authoritative source for later editions. The article takes a look at the various editions of Marina and analyses editorial practices used by Jozef Karol Viktorin and Cyril Kraus.

Klúčcové slová: Andrej Sládkovič, Jozef Karol Viktorin, Cyril Kraus, edičná práca 

textom reprezentujúcim dielo, a ked'že pri každom prenose (transmission) dochádza vždy k odchýlkam textu, ba premenlivost', nestálost' textu je považovaná za jeho prirodzenú vlastnost', nie je zanedbatel'né, koho Marínu čítame, a do akej miery sa odlišuje od východiskového textu. Ked'že od jej vydania uplynulo 175 rokov, pochopitel'ne musela prejst' úpravami, ved' už za Sládkovičovho života sa v pravopise presunul dôraz z foneticko-fonologického princípu na etymologický, čo vyvolalo viaceré zmeny.

V príspevku venujem pozornost' predovšetkým dvom článkom vo vydavatel'skej tradícii Maríny, ktoré v edičnej praxi najviac poznamenali jej súčasnú edičnú podobu - vydania z rokov 1861 a 1961. Vydanie Spisov básnických Andreja Sládkoviča z roku 1861 zveril žijúci autor do opatery Jozefa Karola Viktorina. Ked'že d'alšieho vydania Maríny sa autor už nedožil, dá sa s určitou rezervou hovorit' o vydaní poslednej ruky (čo ešte bude témou d'alšieho výkladu). Práve o toto vydanie sa opiera edícia Cyrila Krausa z roku 1961, na ktorú nadväzujú všetky nasledujúce vydania. ${ }^{1}$ Dnešní čitatelia teda čítajú Marínu „podl'a“ C. Krausa.

Na úvod treba označit pramene, s ktorými som pracoval pri svojom výskume. Dochovaný rukopis so stopami tvorivého procesu označil C. Kraus ako $\mathrm{R}$ (d'alej aj pre plynulost' čitatel'skej recepcie ho vo výklade označujem ako rukopis, zvýraznenie tučným písmom signalizuje, že sa hovorí o konkrétnom prameni uloženom v Literárnom archíve Slovenskej národnej knižnice ${ }^{2}$ ), prvé vydanie Maríny (1846) u Jána Kadavého K (d'alej editio princeps) a Spisy básnické z roku 1861 označil S (Kraus 1956b: 201; d'alej aj v súhlase s Gablerovou inštrukciou Viktorinova edícia). Dielo pripravené C. Krausom (1961) uvádzam ako Krausova edícia. Editor C. Kraus k pramennej dokumentácii Maríny dodáva, že „rukopisy, podl'a ktorých bolo uverejnené jej prvé vydanie roku 1846 a vydanie z roku 1861, sa nezachovali“ (Kraus 1956b: 200). ${ }^{3}$ Dochovaný rukopis Mariny (teda R) dokazuje, že bola napísaná v dvoch fázach. V prvej fáze mala Marína 219 strof. Tento základ je súčastou rukopisného konvolútu s názvom Spevi Andreja Sládkoviča s rozmermi $20 \times 12,5 \mathrm{~cm},{ }^{4}$ ktorý prešiel cenzúrnym procesom. ${ }^{5} \mathrm{~K}$ tomuto konvolútu Sládkovič dodatočne priložil d'alšie listy s rozmermi $18 \times 11 \mathrm{~cm}$, na ktorých rozpracoval d'alších 72 strof (v dôsledku čoho prišlo k prečíslovaniu niektorých pôvodných strof). Práve na základe materiálnej odlišnosti dodatku Pavol Vongrej usúdil, že dopracované strofy vznikli po cenzorskom procese (a teda po predpokladanom vrátení rukopisu Sládkovičovi, teda po 21. júli 1846) a pred septembrom toho istého roku, ked' bolo editio princeps aj s týmito strofami vydané. Samostatný čistopis Maríny

1 Žial', nie každá edícia výslovne uvádza, z ktorého vydania preberá text alebo kto je jej editorom.

2 Slovenská národná knižnica v Martine, Literárny archív, fond Andreja Sládkoviča: Marína, sign. 19 B 5, 19 B 6. Presvedčivú interpretáciu genézy básne podáva Pavol Vongrej v knihe Diamant v hrude, najmä v kapitolách Zrod básne a Tvar básne (Vongrej 1970).

3 Okrem iného o tom svedčia diskrepancie v zneniach rukopisu, editio princeps a Viktorinovej edície.

4 Na konvolúte sa nachádzajú tieto texty: I. Báseň, II. Otázka a odpoved', III. Tajomstva, IV. Hvjézdi, V. [Indián] Zúfalec, VI. Hron, VII. Morava, VIII. More, IX Samota, X. Kikimora, XI. bez názvu (III. sôvet), XII. Otrok, [XIII] XIV. Marína, XIV. Ňehaňte l'ud muoj! (podla Kraus 1961a: 435). Marína zaberá 56 zo 106 listov konvolútu.

5 V rukopise druhého zväzku sa nachádza cenzorská formulka: „Spevi Andreja Szladkovitsa, imprimatur. Neosolii die 21-o Julii 846. Antonius Tilles censor Regius“, vztahujúca sa očividne aj na prvý zväzok. 
s takouto cenzorskou poznámkou, ktorý by niesol stopy cenzúrneho procesu a bol by predlohou editio princeps, sa však nezachoval. Editio princeps bolo teda sádzané z iného, nedochovaného prameňa, nazvime ho pomocne R1. ${ }^{6}$ Otázkou zostáva, čo bolo predlohou pre tlač Viktorinovej edície, a to najmä v súvislosti s tým, že nevieme naisto určit', ktoré zmeny pochádzajú od A. Sládkoviča a ktoré od J. K. Viktorina.

\section{Viktorinova edícia}

Nedostatok priamych dôkazov núti k hypotetickým úvahám. Najpravdepodobnejšie básnik vypracoval pre tlač Viktorinovej edície d'alší rukopis - opät' pomocne - R2 (čo by vysvetl'ovalo výraznejšie zmeny vo Viktorinovej edícii), ${ }^{7}$ do ktorého znenia potom zasahoval aj Viktorin. Zo Sládkovičovej formulácie z listu Pavlovi Dobšinskému 10. apríla 1860 sa zdá, že pre tlač zhotovoval nové čistopisy: "Asi 10 hárkóu mám už pod tlač prepísané“" (cit. podla Kraus 1961b: 84). ${ }^{8}$ Že by sa Viktorinova edícia tlačila podl'a R1 alebo editio princeps s aktualizačnými Sládkovičovými vpismi, je nepravdepodobné, ani rukopis nebol predlohou pre Viktorinovu edíciu, ak len nepočítame s krajnou možnost'ou, že by výrazné štylistické zásahy oproti editio princeps boli editorským podielom J. K. Viktorina.

Ďalším faktorom v uvažovaní sú ,vlastné autorove úpravy, ktoré si urobil vo svojom exemplári, ako sa o nich dozvedáme z listu jeho syna Martina Braxatorisa Jozefovi Škultétymu z 30. mája 1899“ (Kraus 1956a: 90). ${ }^{9}$ Hoci Krausove slová vyvolávajú otázku, či týmto exemplárom disponoval, výslovne to však nikde neuviedol, pričom vo svojej edícii opísal pramene pomerne dôsledne, navyše sa na inom mieste odvolával na Škultétyho tvrdenie o Sládkovičových zápisoch v exemplári (Kraus 1961a: 434), zrejme teda nemal možnost' sám si to overit. ${ }^{10}$

Hned'druhé vydanie Sládkovičovej Maríny, Viktorinova edícia, je zlomom v jej jazykovej úprave. Prípravu mal na starosti skúsený a osvedčený redaktor almanachov Concordia (1858) a Lipa $(1860,1862,1864)$ J. K. Viktorin $(1822-1874){ }^{11}$ Stála pred ním úloha, ako naložit' so Sládkovičovým dovtedajším dielom, ktoré vyšlo v podobe, ktorá už v čase príprav Viktorinovej edície (po hodžovsko-hattalovskej

6 Okrem predpokladaného cenzúrneho postupu o tom svedčia aj rozdiely v zneniach rukopisu a editio princeps. Napriek vedomiu, že rukopis nebol predlohou pre sadzbu, tam, kde išlo o lexikálne alebo štylistické zmeny, uvádzam z neho pre porovnanie variantné miesta. Napokon, ten mohol prípadne byt' nástrojom emendácie pre J. K. Viktorina, ale celkom určite pre C. Krausa.

7 Kraus dospel analýzou variantov $\mathrm{k}$ tomu, že „Sládkovič v snahe odstránit tieto nedopatrenia [v editio princeps - pozn. M. N.] sa pri uverejnení textu v Spisoch básnických len málo vracal k rukopisnému zneniu. Väčšinou prepracovával chybné výrazy v Kadavého vydaní alebo vytváral úplne nové výrazy“ (Kraus 1956b: 201).

8 V korešpondencii sa zachovalo len niekol'ko nepriamych zmienok o rukopisoch, ale bez bližšej špecifikácie.

9 Citát sa vztahuje na Sládkovičov exemplár Viktorinovej edície, existencia podobného exempláru sa však dá predpokladat aj pri editio princeps. Ani spomínaný list M. Braxatorisa J. Škultétymu však nerieši všetky nejasnosti pertraktované v štúdii. Originál listu pozri Slovenská národná knižnica v Martine, Literárny archív, list Martina Braxatorisa Jozefovi Škultétymu, 30. máj 1899, signatúra 49 D 8.

10 Literárny archív Slovenskej národnej knižnice takéto exempláre neeviduje.

11 J. K. Viktorin bol jedným z protagonistov dobového národného hnutia. Známym sa stal najmä redaktorskou a vydavatel'skou činnostou, jeho edičné podniky mali v oblasti techník opätovného vydávania „starších“ diel iniciačnú povahu. Okrem zväzku Sládkovičových spisov pripravil na vydanie Jána Hollého Spisy básnické (1863), Jonáša Záborského Básne dramatické (1865) a d'alšie dve Záborského diela, Bájky (1866) a Lžedimitrijady čili Búrky lžedimitrijovskév Rusku (1866). 
reforme z roku 1851) nebola jazykovo aktuálna, navyše ked' nemohol nájst' oporu v domácej tradícii. Dochovalo sa sedem Sládkovičových listov a dva Viktorinove o spôsobe zaobchádzania s básňami (aj s neuverejnenými a českými), ale aj to, že Viktorin si ujasňuje - čiastočne aj pre čast' zle čitatel'ného Sládkovičovho rukopisu - neisté čítanie niektorých slov či veršov a ich význam.

Viktorin sa v liste z 5. januára 1861 pýta na možnosti pravopisnej aktualizácie textu: „Mám-li sa v potahu na pravopis celkom dl'a mojej gramatiky ${ }^{12}$ spravovat'? čili snad' daktoré odchylky mat' žiadate? Ja bych rád, keby ste to na mňa zveril“ (cit. podl'a Kraus 1961b: 88). Sládkovič mu v liste zo 14. januára 1861 dáva vel'kú vol'nost': „Ohl'adom na pravopis nenazdám sa žeby v rukopisu mojom boly odchylky značné od foriem Vašou gramatikou vystavených: čo viem, že u mňa ,zpev' u Vás ,spev' ,té' miesto ,tie' neutra na ,é' miesto ,ô‘ a t. p. Na všetkom tom mi naskrze nezáleží, a ked' Vám d'aka môžte korrigovat'. Slovom, mne najviac na tom záleží, aby tiskových chyb tam nebolo tolko a takých, ako v Kadavého vydaniu ,Maríny' kde ,bolest' miesto ,belost' nachádzame a t. p." (cit. podl'a Kraus 1961b: 89). Sládkovič sa neskôr pri publikovaní svojich textov v časopisoch prispôsoboval jazykovej reforme. Ale do akej miery donútila táto reforma Sládkoviča otvorit textotvorný proces v „predreformnom“ texte Maríny? Bola jazyková korektnost dostatočným impulzom na to, aby svoje verše preštylizoval? Alebo jej do istej miery dokonca obetoval estetické kvality?

Tradične sa počíta s tým, že vydanie z roku 1861 je autorizované, pretože žijúci autor bol v komunikácii s editorom a poskytol mu súhlas na realizáciu zmien. Určite možno hovorit' o bianco autorizácii, napriek tomu sa možno pýtat', do akej miery bol A. Sládkovič oboznámený s každým krokom editora. Ved'v liste z 13. februára 1861 dovoluje Viktorinovi po svojom zmenit' názov básne: ,ak ho pokrstíte dl'a obsahu ináč, všetko dobre" (cit. podl'a Kraus 1970: 119). Sládkovič mal zrejme možnost' priebežne nahliadnut' do Viktorinovej práce, pretože v liste z prelomu februára a marca 1861 d'akuje za poslanie troch hárkov tlače. V liste z 5 . mája 1861 sa ponosuje na množstvo chýb v texte a navrhuje priložit' ku knižke errata ${ }^{13}$ (teda zrejme v tom čase už bola vytlačená), čo dosvedčuje, že si text Viktorinovej edície prešiel. Na základe niektorých formulácií sa však zdá, že nekládol dôraz na „nedotknutel'nost"“ svojho jazyka ani na detaily, pretože mu napríklad stačí, ked'sa v erratach opravia iba chyby zahmlievajúce zmysel. Je možné, že Sládkovič neporovnával tlač s rukopisnou predlohou, resp. neporovnával ju dôsledne, ale spoliehal sa na svoju pamät' a zaznamenával očividné chyby. No nezachovali sa jeho prípadné výhrady voči samotnej koncepcii Viktorinovho editorského postupu.

12 J. K. Viktorin vydal v roku 1860 knihu Grammatik der slowakischen Sprache.

13 Na záver knihy boli zaradené Opravy, ale aj d'alší Dodatok k opravám Sládkovičových „Spisov Básnických“. Možnost', že pre sadzača bol Sládkovičov rukopis zle čitatel'ný, konštatoval Eugen Krčméry v liste Viktorinovi z 15. decembra 1860, Sládkovičovi sa naň stažoval aj sám Viktorin v liste z 15. januára 1861, niektoré odchýlky môžu byt' teda dôsledkom zlého čítania. 
Viktorin si však uvedomoval aj dôležitost' kolácie. Neprijímal bez problematizácie znenie textu, ale overoval ho porovnávaním s inými prameňmi viažucimi sa k tomu istému dielu. V liste z 15. januára 1861 píše Sládkovičovi: „Básne už vytlačené môžem s rukopisom porovnávat' a tak si pomáhat', ale s novými básňami je bieda. No, však to už len dáko usporiadam“ (cit. podl'a Kraus 1972: 480). Sládkovič v liste $\mathrm{z} 13$. februára 1861 a v d'alšom približne z februára či marca 1861 vysvetl'oval Viktorinovi jednotlivé slová v básňach (na ktoré sa v nedochovanom liste musel Viktorin pýtat'), čo vypovedá o editorovej citlivosti na detaily.

$\mathrm{V}$ prípade Maríny od editio princeps $\mathrm{k}$ Viktorinovej edícii pochopitel'ne prišlo k zmenám. V prvom rade treba spomenút', že od tohto vydania je súčastou skladby aj známe Venovanie. Po reforme pôvodnej štúrovskej kodifikácie boli zavedené ypsilony, vokáne, zrušené mäkčene na d, t, n, l po i alebo e, zápis dvojhlásky ňje, zpomjenka ako nie, zpomienka atd'. Objavujú sa aj úpravy interpunkcie, zrevidované je písanie slov spolu a dovedna (svatjebich na sväté bych, tjetobi na tieto by, dvaraz na dva ráz; s hora na zhora, po prvuo na poprvé atd'.). Zámená Ona, Jej a podobne boli pravopisne (pravda, aj s miernou zmenou sémantiky) upravené na ona,jej.

Okrem toho je vo vydaní viacero morfologických úprav. Štúrovské neutrum typu štestjja sa upravuje na štastie atd., prídavné mená v neutre mladistuo, tichuo sú upravené na mladistvé, tiché atd'.; prídavné mená svatje, hodbabnje, bledje, hroznje, ňevinje na sväté, hodbabné, bl'adé, hrozné, nevinné; cudzja je po novom cudzá. Tvar vuoňe sa prepisuje ako atribút vonné („Fialky vonné dýchat' prestaly“; tu sa núka otázka, či nejde o inverziu nezhodného prívlastku vôňe fialky) i príslovku vonne („A kvety zase vonne dýchajü“). ${ }^{14}$ Slovesné tvary minulého času ňeostau, prereknuv, pretrhnuv, trhnuv sú upravené na nezostal, prerieknul, pretrhol, trhnul atd'; tretia osoba plurálu sa od slovesa byt' je upravená na sú.

Vo Viktorinovej edícii boli niekde oproti editio princeps zdvojené hlásky: pokoní na pokonný, ňevinje na nevinné, ňevinej na nevinnej. Úprava krivokí na krivooký spôsobila slabičný posun, ktorý musel byt' kompenzovaný: „Teutonská závist', či blud krivoki“ na „Teutonská závist', blud krivooký. Ďalej prišlo k zmene predložkovej väzby do duši na ku duši (zrejme motivovaná potrebou zachovat rým a zároveň sa vyhnút neželanému tvaru genitívu singuláru $d u s ̌ i)$, pred vlastnou na podvlastnou a podobne.

Prítomné sú aj doklady o zmene deklinácie: „vjaže kvetín slobody“ na „viaže kvetov slobody“; „Strašňe osúda víchrice..." na „Strašné osudu víchrice..."; srdcou prjestorám na srdcí priestorám; „Ružovích tvár hladkost'jará“ na „Ružových tvári hlad'jará“; „Pime dvojich slastí vlahu“ na „Pime dvojej slasti vlahu“; „A spev v kole d'evíc..." na „A spev v kolu devíc...". Tiež možno pozorovat' premeny v lexikálnej oblasti, často sprevádzané prehodnotením ortografickej sústavy, pričom viaceré posuny svedčia o intenzívnych kontaktoch s češtinou: ako na jako; dlažbou na dlážkou; dvojme na dvojmo; farby na barvy; glgotaňi na blbotaní; hmlách na mhlách;je (sloveso jest) na ji; jích na ich; ko mňe na ku mne; kolo na vôkol; krjedlach na krídlach; liliach na l'aliach; ljevancou na liatovcov; nahá na nechá; nach na nech; náručňice na náramnice; nazpet na nazpak; ňeoberá na nezoberá; ňjeto na nenie;

14 Ak to nebola Sládkovičova úprava, mohlo by to naznačovat', že predloha pre tlač bola ešte v štúrovskej slovenčine. 
okomih na okamih; ostaňe na zostane; peri na rtíky;počím na pokial; ptáčka na vtáčka; raňej na rannej; ruoj na roj; divok na divoch; spovlekom na spovlakom; skočňe na

(zároveň zmena interpunkcie) a podobne.

Štylistické úpravy prebehli formou úpravy slovosledu: „,milje moje kveti“ na „moje milé kvety“, skvjetim polňim na spolným kvietim, hmli mraznje na mrazné mhly atd'. od menej závažných zmien lexém: „A centrom, živlom, ňebom, jednotou“ na „No, centrom, živlom, nebom, jednotou“; Šakzdá sa... na Ležzdá sa...;Len vo fabrikách... na A vofabrikách...;Leč toje... na Ležtoje...; ,... preštáastní čojakpoddani"na „... prešt'astní kdo jak poddani“; Tu sú modljacej... na To sú modliacej...; Ale vln zlatích... ${ }^{15}$ na Jako vín zlatých...; úprava zámen svojim na mojim (35. strofa) a tvojich na svojich (159. strofa) a podobne; až po závažnejšie zmeny: „Ako ked'vetríkv škárach Ďevina“ na „Jako ked'vetríkv hradbách Devina“; „Zlúpi táa zem z tích bohatích" na „Zlúpi t'a svet z tých bohatých“; „A ved'je búrkou"16 sveta nás“ na „A vedie búrkou žitia nás“; „Na hori Sitna letela“" na „Na hory tieto letela“; „V ňedbalkách, to v raňom stíne " na „Vnedbalkách, to v mladom stíne“ (už tu sa kreoval postup zachovat' slovo v rýmovej pozícii, kým vo vnútri verša sa menilo na tieň); „A blesk nád'ejí z tvári mu svjeti" na „A blesk úfania z tvári mu svieti“; „Ačv druhej ducha podobe" na „Ač vinej ducha podobe“; „Ces všetki tvojho sveta krajini“ na „Cez všetky tvojho žitia krajiny“; , ,Všetko objatím vrelím stvrd'ila“ na „V̌̌etko objatím verným stvrdila“; „Asnad' jazikou slaních klebeta“ na „Asnad'jazykov zlostných klebeta“; „V medze úzke zvik zavjera“ na „V medze úzke svet zaviera“; „Kd'e žrjedla sú blaženích krás“ na „Kde žriedla sú blaženstva krás"; „Ja sa Ťi ňeznám ináče korit" na "Ja sa ti neviem ináče korit"; „Na slasti peknje, bohatje“ na „Na sladké slasti bohate“" (ak tým bol vystihnutý Sládkovičom zamýšlaný význam, potom bol verš aj spriezračnený); „Otrjasli farbi sveta veselje“ na „Otriasly barvy svoje vesele“; „Počúvaš dutuo hučaňja Hrona“ na „Počuješ duté hučanie Hrona“ (neskôr to reštituoval Kraus); „Či vješ, čo huk ten znamená?" na „Vieš ty, čo huk ten znamená?"; „V účast'bravom...“" na „V účastlivom...."; „Druhou srdcja objímali!“ na „L'avou srdcia objímali!“; „Plet'jej hodbabná z bjeleho čela“ na „Plet' jej hodbabná z vábneho čela“ atd'. Vo variantných veršoch „A s klúčom hrá v ruke zlatím“ - „A s klúčom hrá ruka zlatým“ sa mení agens (mladuchu z predchádzajúceho kontextu strieda $r u k a$ ) a v dôsledku toho aj pád. Ale napríklad varianty „A ňezabudki tícho sluchali“ - „A nezabudky tieto slúchaly“; „A sňivaj tichje sni žitja“- „A snívaj tichédni žitia“; „A družki moje hňed'sa zamorja“ - „A družky moje hned'sa zanoria“ a „V ktorích mrje Vila - Marina“ na „V ktorých vre Vila-Marina“ mohli vzniknút' chybným čítaním predlohy.

Aj v rozpore s dochovaným rukopisom bol opravený narušený slabičný rozmer verša „Ti počúvaš, ked'slávikvzdicha“na „Ty čuješ, ked'slávikvzdychá"; „Aj žit'aj mrjet?'? - chlap ostíchavi“" na „Aj žit', aj umret'? - chlap ostiechavy". Ked'že nepoznáme Viktorinovu predlohu pre tlač, tažko určit', či prijímal Sládkovičovo nové znenie, pristupoval k emendáciám (podla iného prameňa) či ku konjektúram, alebo

15 V rukopise: Ako vln zlatích...

16 V rukopise: búrmi. 
aktívne redaktorsky zasahoval. Každopádne počet slabík vo verši je opravený aj v posune (analogickom s rukopisom) „Vstát' mám kde Hron sa toči" na „Zostat' mám, kde Hron sa toči"; „... ak ňje slepi“" na „... akje nie slepy'“; „Už sa hore Čertovej Svat'be“ na „Už sú na hore Čertovej Svatbe“. A už v rukopisnom verši „Tak mislité aj vi, Hole " bolo prepisované Hole, ktoré narúšalo strofickú schému, no preniklo do editio princeps, na hori (rýmujúce sa s veršom „Duch muoj chrám ten ňerozborí!“), čo bolo vo Viktorinovej edícii napravené. Naopak, zmenou verša „Prázni bozskosti Boha ňeslávi“ na „Prázny božskosti Boha nevzýva“ sa narušil rým, resp. strofická schéma, ${ }^{17}$ a zmenou v rýme plema / ňemá na plemä / nenie sú zase oslabené jeho zvukové kvality. Normalizáciou boli pokazené napríklad aj rýmy bledí / vtedi na vtedy / bladý (strofa 84), koleje / nád'eje na kolaje / nádeje (strofa 174), bolastí/ slastína bolestí/ slastí (strofa 277) a podobne. Čítanie verša, v editio princeps znejúceho „Zdá sa, že hrozni ztïchlej víchrici“, ktoré bolo vo Viktorinovej edícii upravené na „Zdá sa, že hrúzy ztíchlej víchrici“, nie je úplne bezpečné. Ono hrozni, hrúzy možno v rukopise (obrázok 1) prečítat' aj ako hromi (čo v Sládkovičovej neustálenej kvantite zrejme znamenalo hromy):

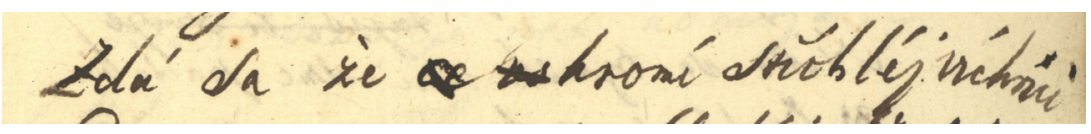

Obrázok 1

Zmysel zmeny podmetu z „Aj tam sa jaro trávki usmjeva“ na „Aj tam sa trávka jaru usmieva" nie je celkom priezračný, azda pôjde o spresnenie vyjadrenia. Ak predpokladáme, že by si Viktorin nedovolil tak radikálne zasahovat' do Sládkovičových textov (čo by bolo nad rámec proklamovaného povolenia spravovat' pravopis podla jeho gramatiky, o ktoré v korešpondencii žiadal), javí sa existencia R2 pravdepodobná. ${ }^{18} \mathrm{Na}$ druhej strane je t'ažko predstavitel'né (aj ked'nie nemožné), že by sám básnik svoje verše transformoval s takou puristickou vášňou, aby deformoval estetické kvality svojho textu do takej miery, že vytváral iba nepresný rým (strany rýmu kol'aje - nádeje sa obmedzujú na jednoslabičnú rýmovku je).

J. K. Viktorin svojou prácou kládol základy slovenskej edičnej praxe. K plánovanému vydaniu druhého zväzku Sládkovičových spisov nakoniec nedošlo, Viktorin už zakrátko pracoval na príprave edície poézie J. Hollého. ${ }^{19}$

17 Defekt strofickej schémy sa nachádza napríklad ajv 172. strofe Detvana vo Viktorinovej edícii, kde miesto Martin náś, rýmujúceho sa s Tu ho máš, je znenie Martin môj, ktoré sa v inom prameni nenachádzalo. 18 Na porovnanie, pri pohl'ade na posuny medzi uverejnením básne Sokoli (Sládkovič 1860: 1) v poreformnom období v časopise Sokol a Sokoly vo Viktorinovej edícii nie sú zjavné markantné zásahy: $t i ́$ sokoli - tie sokoly (v závislosti od toho oni videli - ony videly); vokatív otče - otec; ,... skryt'sa v tam ty skaly“ - „... skryt'sa tam v tie skaly“; povest-povest'; oziva - ozýva; sneh - sňah, snežnou-sňažnou; synák-synak; mohútny-mohutný; kriedlach-krídlach;cherub-Cherub; v Spisoch básnických je zrušené odsadenie priamej reči. Závažnejšou odchýlkou je odlišné čítanie: obrom - orlom.

19 V tejto edícii J. K. Viktorin už svoje zaobchádzanie s textom aj explicitne formuloval. Vo svojej štúdii sa problematikou edícií bernolákovských textov zaoberal Miloslav Vojtech (2020). Je príznačné, že A. Sládkovič, ktorý v liste z 5 . augusta 1862 rázne odrádzal Viktorina od radikálnych intervencií do Hollého bernolákovčiny, bol až príliš benevolentný k Viktorinovým zásahom do vlastnej poézie. Pravdaže, nemalú rolu v tom zohrali rozdielne verzifikačné systémy. 
Medzi Viktorinovou edíciou a Krausovou edíciou vyšlo - či už samostatne, alebo ako súčast' spisov - d'alších pätnást' vydaní Maríny. O jej edičné uchopenie sa postarali napríklad Jozef Škultéty, Jakub Šebesta či Ján Brezina. Vo vývojovom rade edičných riešení Maríny je z dnešného hladiska posledným výrazným krokom Krausova edícia pripravená ako 56. zväzok edície Naši klasici. Edícia začala nastavovat' vyšší štandard textologického skúmania a edičnej starostlivosti, aká dovtedy nemala na Slovensku obdobu (a dodnes nie je samozrejmostou).

C. Kraus pomerne starostlivo opisuje materiálnu i obsahovú podobu väčších pramenných celkov, zhromažduje rôznočítania a v súlade s tými lepšími tradíciami slovenskej edičnej praxe poctivo opisuje svoje editorské postupy a jazykovú aktualizáciu textu. Niečo, čo fakticky supluje úlohu lemmatizovaného rôznočítania či variantov k Maríne, rozdeluje Kraus na dve funkčne zamerané časti. Prvá čast' rôznočítaní je pri bibliografickom opise prameňov Maríny a k variantu z Krausovej edície prirad'uje „odchýlky“ rukopisu a editio princeps, aby sa nimi manifestoval vývoj Sládkovičovej poézie. ${ }^{20}$ Nezachytáva tie prípady, ked' sa podla neho varianty odlišujú len v grafickom zápise (v skutočnosti vymenováva aj javy, ktoré prekračujú rámec grafickej odlišnosti, za všetky uvediem zmeny základného tvaru minulého času slovies bou - bol, mau - mal, český vplyv na písanie zámen jich, jim, jaki, kdo, častice jako, jak a podobne). Aj ked' Krausovo vymedzenie nie je presné, poskytuje záujemcovi informatívny prehl'ad, na základe ktorého sa dá aspoň približne rekonštruovat pôvodné znenie. Väčší problém tvorí rozkolísaná kvantita a mäkkost'hlások, ktoré sú rozkolísané aj vo vnútri Sládkovičovho systé$\mathrm{mu}$, čo názorne ilustruje incipit prvej strofy rukopisu (obrázok 2):

„Já sladkjé tužbi, túžbi po kráse“

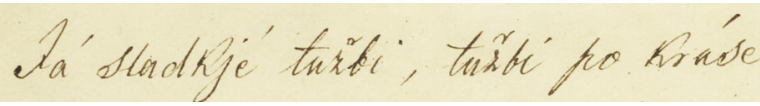

Obrázok 2

Druhá čast' rôznočítaní je v časti Textová úprava a po predchádzajúcom všeobecnom opise jazykovej aktualizácie Krausovej edície sa sústreduje na jednotlivé „úpravy“ od Viktorinovej edície k edične ustal'ovanému textu Krausovej edície. ${ }^{21}$

Za východiskový text svojej edície Maríny (ale aj d'alších textov) si C. Kraus zvolil text Viktorinovej edície. Ked'že Marína vyšla za života A. Sládkoviča dvakrát $(1846,1861)$ a text vo vydaní poslednej ruky neprešiel úpravami, ktoré by ho v očiach editora diskvalifikovali (ideologické deformácie, cenzúra, puristické hladiská poškodzujúce estetickú stránku diela a podobne), ba naopak, bolo obohatené o venovanie, a ked'že sa navyše jazyková aktualizácia textu blížila súčasnej podobe slovenčiny, táto vol'ba sa zdá byt' logickým riešením. Podla Krausa bol Sládkovič „,v plnej miere zainteresovaný pri úpravách svojich básni“, knihu

20 Zápis variantných znení v Krausovej edícii na stranách 445-454.

21 Úpravy v Krausovej edícii na stranách 604-606. 
údajne „dôkladne prezrel“ (Kraus 1956a: 90), pretože „vel'mi mu na tom záležalo, aby v texte neboli nijaké chyby“ (Kraus 1961a: 599). ${ }^{22}$ Viktorinovu edíciu teda považuje za spol'ahlivo autorizovanú Sládkovičom, a preto za smerodajnú. Ako teda narába C. Kraus so „zdedenou“ úpravou?

Vo všeobecných zásadách textovej úpravy celého zväzku sa prejavuje snaha vysporiadat' sa s českými a nárečovými zvolenskými tvarmi, i ked' trochu nadbytočne. C. Kraus totiž informuje aj o zmenách, ktoré vychádzajúc z Viktorinovej edície nemusel robit' (Kraus 1961a: 602-603). Editor paušálne uplatnil podl'a platnej kodifikácie úpravu interpunkcie, písanie predložiek s, z, predpôn s-, z- a ich vokalizovaných podôb, zjednotil zakončenie slovies minulého času v pluráli, písanie slov dovedna a oddelene, písanie cudzích slov podl'a dnešnej normy, normalizoval rozkolísanú kvantitu i mäkkost' hlások, urobil opravy v hláskosloví (vetor - vietor, hrúza - hrôza atd'.), upravil pravopisné konvencie slov, kde mali zásahy minimálny zvukový efekt (dvadcat'-dvadsat', predca - predsa, l'alija - l'alia a podobne), ale podla aktuálnej normy upravil aj štúrovské tvary prídavných mien (ostatnia - ostatná, drahô-drahé, rodnieho-rodného atd'), podstatných mien stredného rodu v nominatíve singuláru (zbožia - zbožie, sklepeňja - sklepenie atd'.) či slovies (obzierat'-obzerat', riastla - rástla atd'). Aktualizujú sa pádové koncovky (všetke - všetky, hradôb - hradieb, nožičôk - nožičiek, chlievach - chlievoch atd'), písanie zámen (jich-ich, jim-im, kdo-kto, častíc jako-ako,jak-ak), tvary morfém (krúta - krútia, vába - vábia, dušam - dušiam, klatba - kliatba, čahat' - čiahat' atd') a slovesné tvary (videt' - vidiet', letet'-letiet', mre - mrie, zre - zrie atd'.). Zrušil konvenciu písania prvého slova verša zásadne vel'kým písmenom.

Popri vykonaní nutných zásahov bolo ciel'om C. Krausa „zachovat autorovu koncepciu, ktorá sa prejavuje popri syntaktických a lexikálnych zvláštnostiach aj vo výbere básní, aj v ich začleneni““ (Kraus 1961a: 424). Treba mat' na pamäti, že nie je k dispozícii zaručená vedomost', kto bol pôvodcom ktorých posunov vo Viktorinovej edícii (a do akej miery to boli Sládkovičove zvláštnosti), ktoré sa stali neskôr východiskovým textom Krausovho vydania. Niekol'ko rokov pred vydaním Krausovej edície jej editor napísal, že ,rôznorodost' textov nemôže nás však zvádzat' k tomu, aby sme si z nich skonštruovali taký text, ktorý by čo najlepšie vyhovoval našim požiadavkám, pretože sme upozornili na organický vývoj textov od znenia rukopisného cez znenie Kadavého vydania k vydaniu textu v Spisoch básnických" (Kraus 1956b: 206). Kraus tým vlastne demonštratívne odmieta eklektické znenia, ktoré boli už v prvej polovici pätdesiatych rokov kritizované v súvislosti s vydávaním diela Jozefa Gregora Tajovského Karolom Rosenbaumom, ale vzápätí predsa dodáva: „Iba na niekol'kých málo miestach bude treba prihliadat' k presnejšiemu rukopisnému zneniu“ (Kraus 1956b: 206), čím vlastne pripúšta nutnost' emendácií a možno naznačuje dokonca kontaminácie a spochybnenie autorizácie. Napokon šiel aj za normalizáciu pravopisu a opravu koruptel.

Ilustratívne uvádza emendácie, „kde máme oporu v rukopisnom zneni““ (Kraus 1961a: 600), pravda, v rukopise, ktorý nebol predlohou tlače. Reštituuje znenie v 42. strofe (nesprávne „Bájočním barvám mojich výrazov / Zázračným

22 Aj pri rozsiahlosti zväzku tomu čiastočne protirečí, že Sládkovič si nevšimol v Detvanovi vynechanú strofu, ktorá v dôsledku toho „bola uverejnená prvý raz až vo vydaní Detvana v Hviezdoslavovej knižnici 1952 pod číslom 223a, aby sa nenarušilo tradičné číslovanie strof Detvana“ (Kraus 1961a: 493). 
tváram mojich obrazov“ podl'a rukopisu: „Bájočním tvárám mojich vírazóv / Zázračním farbám mojích obrazóv") či v 99. strofe (tam boli vymenené rýmové slová rozlúčit'-umučit). Zaujímavé je riešenie v 64. strofe. Kraus podnietený rulkopisným znením „Pre mňa nach trebas žrjedlo sladkosti"“ mení slovo treba z Viktorinovej edície („Pre mňa nech treba žriedlo sladkosti“) na trebárs: „pre mňa nech trebárs žriedlo sladkosti“. Dochádza tu teda k posunu na osi trebas-treba-trebárs.

$\mathrm{Na}$ jednej strane sa reštituujú niektoré pokazené rýmy z Viktorinovej edície (mojej / kol'aj, bolestí / neštastí a podobne), na druhej strane bola ponechaná narušená kvalita rýmov z Vilktorinovej edície, ked' sa z nich v snahe dodržat' jazykovú korektnost' normalizovaním tvarov minulého času slovies vytvárali asonancie (citov / svitol, zrodil / to div, aj ked' „rým“ prirástol / bolest'ou z vydania z roku 1861 Kraus upravil na prirástol / bol'astou). Potvrdzuje sa prax, že tam, kde po normalizácii tvaru zostala aspoň asonancia, pristúpilo sa k nej, tam, kde by nebola ani len asonancia, ponechalo sa v rýmovej pozícii nespisovné slovo (stín $/ s y n$ ). Vo vnútri verša sa však slová normalizujú (tieň), čím vzniká dvojité riešenie, ktoré v editio princeps nebolo. Do istej miery sa tak prejavuje fóbia zo slov vymykajúcich sa norme: „Viktorin upravoval slovo hmla na mhla,jelša na jalša, jeseň na jaseň, sneh na sňah, farba na barva, striebro na sriebro, bledý na bl'adý. V týchto prípadoch ponechávame pôvodné Sládkovičovo znenie“ (Kraus 1961a: 602), čím sa znenie Viktorinovej edície kontaminuje so znením editio princeps. Rukopisné predci píše Kraus raz ako predsa, inokedy predsi.

Oprávnenú pochybnost'vzbudzuje Krausovo tvrdenie, že by práve básnik pokazil svoje rýmy, že by „pri prepise z pôvodného fonetického pravopisu do etymologického neprihliadal na to, či sa oslabí alebo naruší rým" (Kraus 1956b: 201). Nevieme, či pôvodcom týchto zmien bol naozaj Sládkovič, a tiež to protirečí nasledujúcemu Krausovmu tvrdeniu, že „Sládkovič sa stále vracal k svojej poézii, že stále zdokonal'oval jednotlivé výrazy“ (Kraus 1956b: 204). So slovami o autorite autorizácie Viktorinovej edície kontrastuje spochybňovanie d'alších úprav. Pri absencii prameňa, ktorý bol predlohou pre tlač Vilktorinovej edície, nemáme ani pri nich istotu, od koho pochádzajú jednotlivé posuny. (Alebo sa možno uspokojit s tým, že sa Viktorinovi mechanicky prisúdia iba gramatické a morfologické zmeny?) Otázka autorstva zásahov je o to nástojčivejšia, že normovaním niektorých tvarov sa kazili napríklad rýmy. Sládkovič síce zdôrazňoval, aby v texte neboli chyby, ale jeho plná zainteresovanost' na vydaní vlastných básní bola oslabená delegovaním právomocí na Viktorina.

Autorizácia predpokladá, že autor sa so zmenami oboznámil a odsúhlasil ich. V tom prípade nie je dôvod, aby bol východiskový text kontaminovaný inými zneniami. Napriek tomu sa C. Kraus vo viacerých prípadoch vracia k zneniu rukopisu (prípadne k editio princeps), napríklad (uvádzam v poradí rukopis - Viktorinova edícia - Krausova edícia):

„V ňedbalkách, to v raňom stïňe“ - „V nedbalkách, to v mladom stine“ - „vnedbalkách, to v ranom stíne"

„A ňezábudki ticho slúchali“- „A nezabudky tieto slúchaly“- „, a nezábudky ticho slúchali“

„Počúváš dutuo hučaňje Hrona?“ - „Počuješ duté hučanie Hrona?“ - „Počúvaš duté hučanie Hrona?" 
Inde však ponecháva znenie Viktorinovej edície oproti odlišnému

zneniu rukopisu (rovnaké poradie ako v predchádzajúcich príkladoch):

„Asnad'jazikóv slanich klebeta?“ - „Asnad'jazykov zlostných klebeta?“" „Asnád'jazykov zlostných klebeta?"

„A družki moje hned'sa zamorjá" - „A družky moje hned'sa zanoria“ - „a družky moje hned'sa zanoria“

čo hukten znamená?"

„Či vješ, čo hukten znamená?“ - „Viešty, čo hukten znamená?" - „Vieš ty,

„Plet' jéj hodbabná z bjeljeho čela“ - „Plet'jej hodbabná z vábneho čela“ - „Plet'jej hodvábna z vábneho čela“

Nie je vždy ani jasné, podl'a akého kritéria editor raz prijal Viktorinovo riešenie, inokedy sa vrátil k zneniu rukopisu. Na základe čoho považoval niečo za Sládkovičovu revíziu, d'alšie za Viktorinovu „licenciu“, iné za pochybenie? Urobil tak iba na základe subjektívneho postoja, domnienky? Neautorské zásahy odôvodňuje napríklad tým, že „slovo hádam Sládkovič vo svojej poézii používa vel'mi málo a do S sa dostalo mechanickým prevzatím z K“ (Kraus 1956b: 204). Je to bystrý postreh, ale ak už prijal princíp autorizácie Viktorinovej edície Sládkovičom, ak hovoril o dôslednom prezretí a plnej Sládkovičovej zainteresovanosti na vydávaní, nie je celkom namieste opakovane to spochybňovat' (samozrejme, preklepy a podobne sú relevantným objektom emendácie). Ak spochybňujeme autorizáciu, spochybňujeme vlastne legitímnost' východiskového textu.

Napokon, o nedostatočnej spol'ahlivosti vydania svedčí aj to, že Sládkovič hovoril o mnohých chybách v ňom. No tým, že navrhoval opravit' len tie, ktoré rušia, zahmlievajú význam (v liste z 5. mája 1861), ponechal vlastne zastreté a pochybne identifikovatel'né autorstvo d'alších javov, ktoré síce považoval za chybu, ale netrval na ich označení a opravení v errátach. K tomu sa pridružuje okolnost', že Sládkovič nemusel texty skontrolovat' dostatočne ostražito, pretože nekontroloval iba Marínu, ale celú 392-stranovú Viktorinovu edíciu, a okrem toho tlačil na skoré vydanie knihy, aby napokon projekt nestroskotal z dôvodu nestabilnej spoločensko-politickej situácie. Mohlo by sa azda uvažovat'aj o tom, že práve z tejto príčiny neotváral básnik otázky niektorých zásahov J. K. Viktorina.

\section{Namiesto záveru}

C. Kraus je posledným editorom, ktorý významne zasiahol do vydavatel'skej tradície Maríny a na dlhý čas určil jej recipovanú podobu. V takejto podobe je známa mnohým generáciám slovenských čitatel'ov. Aj ked' si za východiskový text zvolil Viktorinovu edíciu, na viacerých miestach reštituoval znenie podla rukopisu, č́m jednak vytvoril eklektické znenie, na druhej strane v rozpore so svojím tvrdením naznačil, že Viktorinova edícia nie je celkom spolahlivá. Vol'ba Viktorinovej edície vzhl'adom na predpokladanú (a najmä vyhlasovanú) autorizáciu a jazyk približujúci sa súčasnej norme by bola pochopitel'ným riešením. C. Kraus však nezachoval integritu svojho východiskového textu. 

kritike textu. ${ }^{23}$ Od tohto posledného relevantného editorského prehodnotenia Maríny uplynulo vyše šest'desiat rokov. Azda by si text Maríny, vol'ba jej východiskového textu a miera editorských intervencií do neho, jej vydavatel'ská história zaslúžili revíziu. Eventuálne nové edičné uchopenie nemusí byt' nevyhnutne zlomom vo vydavatel'skej tradícii Maríny, nemusí byt' negáciou edičného riešenia C. Krausa, ale možno na ňu nadviazat' a v jednotlivostiach ju korigovat' (a to aj so zachovaním niektorých zaužívaných postupov v slovenskej edičnej praxi). Bude si však vyžadovat' zdôvodnenie jednotlivých krokov, ktoré by transparentne nastolilo presvedčivú podobu textu a umožnilo by postup tohto ustal'ovania textu reflektovat' aj budúcimi editormi. Editor Maríny si bude musiet' odpovedat' na otázku, či berie Sládkovičovu autorizáciu Vilktorinovej edície vážne, prípadne do akej miery. Pravda, predchádzajúce slová o revízii textovej podoby platia aj o zvyšnom diele A. Sládkoviča, Marína je tu len ilustratívnym príkladom.

Štúdia je výstupom projektu VEGA 1/0416/19 Textologickýa edičný výskum vybraných reedícií básnických zbierok vydaných od druhej polovice 20. storočia po súčasnost'. Zodpovedná riešitel'ka: Mgr. Veronika Rácová, PhD. Doba riešenia: 2019-2021.

\section{Archivne pramene}

Slovenská národná knižnica v Martine, Literárny archív, fond Andreja Sládkoviča: Marína, sign. 19 B 5, 19 B 6.

Slovenská národná knižnica v Martine, Literárny archív, list Martina Braxatorisa Jozefovi Škultétymu, 30. máj 1899, sign. 49 D 8.

\section{Pramene}

KRAUS, Cyril, ed., 1970. Korešpondencia Andreja Sládkoviča. Martin: Matica slovenská.

SLÁDKOVIČ, Andrej, 1860. Sokoli. Sokol, roč. 1, č. 4, s. 1.

SLÁDKOVIČ, Andrej, 1861. Spisy básnické Andreja Sládkoviča. Ed. Jozef Karol Viktorin. Banská Bystrica: Eugen Krčméry.

SLÁDKOVIČ, Andrej, 1961. Dielo I. Ed. Cyril Kraus. Bratislava: Slovenské vydavatel'stvo krásnej literatúry.

\section{Literatúra}

GABLER, Hans Walter, 2013. Editing Text - Editing Work. Ecdotica, roč. 10 , s. $42-50$.

KRAUS, Cyril, 1956a. Dnešná problematika vydávania diela Andreja Sládkoviča. Slovenská literatúra, roč. 3, č. 1, s. 88-93.

KRAUS, Cyril, 1956b. K problematike vývoja textov Maríny. Slovenská literatúra, roč. 3, č. 2, s. 189-207.

KRAUS, Cyril, 1961a. Poznámky. In SLÁDKOVIČ, Andrej. Dielo I. Ed. Cyril Kraus. Bratislava: Slovenské vydavatel'stvo krásnej literatúry, s. 423-612.

KRAUS, Cyril, 1961b. Sto rokov od vydania Sládkovičových Spisov básnických. Slovenská literatúra, roč. 8, č. 1, s. 80-96.

KRAUS, Cyril, 1972. Andrej Sládkovič. Bratislava: Osveta.

VOJTECH, Miloslav, 2020. Problematika edícií a jazykových aktualizácií bernolákovských literárnych textov. Slovenská literatúra, roč. 67 , č. 4, s. 287-305.

VONGREJ, Pavol, 1970. Diamant v hrude. Martin: Matica slovenská.

Mgr. Martin Navrátil, PhD.

Ústav slovenskej literatúry SAV

Dúbravská cesta 9

84104 Bratislava

Slovenská republika

E-mail: Martin.Navratil@savba.sk

23 Napríklad v siedmom verši 241. strofy je chybný verš „zhmlia život nášho žitia“, ktorý sa potom pri absencii kritiky textu (okrem ojedinelých výnimiek) mechanicky preberal z Krausovej edície do reedícií vlastne až do dnešných dní. 